\title{
Petrol Induced Alteration in Enzymes and Electrolytes in Tympanotonus fuscatus after Exposure
}

\author{
Edori, O. S. ${ }^{1}$; Edori, E. S. ${ }^{2}$ and Festus, C. ${ }^{1}$ \\ ${ }^{1}$ Department of chemistry, Ignatius Ajuru University of Education, PMB 5047 Rumuolumeni, Port Harcourt, \\ Nigeria \\ ${ }^{2}$ Government Comprehensive Secondary School Mbiama, Ahoada West,Rivers State Nigeria
}

\begin{abstract}
Tympanotonus fuscatus collected from the New Calabar River were exposed to different concentrations of petrol $(10.40,15.60,21.00$ and $26.00 \mathrm{ml} / \mathrm{L})$ and a control for six days to determine the activities of enzymes, aspartate transaminase (AST), alanine transaminase (ALT) and alkaline phosphatase(ALP) and electrolytes namely sodium $\left(\mathrm{Na}^{+}\right)$, potassium $\left(\mathrm{K}^{+}\right)$and chloride $(\mathrm{Cl})$ in the tissues of the organism. There was a marked increase in the activities of all the enzymes in the viscera of Tympanotonus fuscatus with ALP being the most prominent enzyme. ALP was highest at $26.00 \mathrm{ml} / \mathrm{L}(390,00 \pm 70.71 I \mathrm{I} / \mathrm{L})$ which was $2 \mathrm{X}$ and $3 \mathrm{X}$ that of AST and ALT respectively at $10.40 \mathrm{ml} / \mathrm{L}$. In the muscle, elevation of activity was observed in AST only while ALT and ALP declined in all the exposure concentrations with AST being the most prominent enzyme. The levels of the electrolyte $\left(\mathrm{Na}^{+}, \mathrm{K}^{+}\right.$and $\left.\mathrm{Cl}\right)$ all declined in value in comparison to the control in the viscera of Tympanotonus fuscatus. The most prominent ion was sodium followed by chloride and finally potassium. In the muscle, decrease in levels was also observed in all the ions except at $15.60 \mathrm{ml} / \mathrm{L}$ and $26.00 \mathrm{ml} / \mathrm{L}$ for sodium and ions respectively. The increase or the decrease observed in either the enzymes or the electrolytes did not follow any pattern.
\end{abstract}

Key words: Pollution, Tympanotonus fuscatus, petrol, enzymes, electrolytes, environment

\section{Introduction}

One of the environmental consequences of crude oil or petroleum exploration and exploitation is oil pollution and this has been found to cause serious aquatoxicological effects that are deleterious to aquatic life (Agbogidi et al.,2005). The domestic and industrial use of its crude or refined form has rapidly increased in recent times. Diesel, kerosene and petrol are the most commonly used fraction of crude oil (EHC 20,1992). Unsaturated hydrocarbons at different concentrations are found to be entrained in these fractions thereby causing variable toxicities to aquatic organisms (Kato et al., 1996).

During oil spills, a number of physical and chemical properties such as evaporation, dispersion, emulsification, sedimentation, biodegradation and photo-oxidation are altered which help in the distribution and partitioning of petroleum components into the water, organisms and sediments (Clark, 1992). Hydrocarbons are quantitatively the most important component or constituent of petroleum and arise from both natural and anthropogenic sources (Law and Biscaga, 1994). However, among the anthropogenic sources, point source contamination by run-offs, refineries and other coastal effluents are in substantial amount and are important in causing chronic pollution in the vicinity of estuaries, creeks, harbour and coastal settlements (Abu-Hilal and Khordagui, 1994). Petroleum hydrocarbons are among the most common contaminants bound to estuaries and sediments (Medeiros et al.,2005; benson et al., 2008). These substances, mostly of organic origin may be deleterious to aquatic plants and animals and may cause damage to wildlife and fish (Atlanta, 1994).

Tympanotonus fuscatus is a group of molluscan shellfish with either smooth or rough spiral shells. They are found in the inter tidal zones at low tide in several parts of the world (Doerffer, 1992). It is a dominant species in West African coastal lagoon and also a high source of animal protein. Periwinkles crawl about under water but usually remain passive when left uncovered by the tide. They feed on microscopic algae, detritus matter and diatoms and have been found to be rich in protein and carbohydrate (Egonmwan, 1980). It is a delicacy and competes favourable with tilapia catfish in marketability in the Niger Delta area of Nigeria.

This study is carried out to investigate the effect of petroleum product, petrol (gasoline) on the tissue enzymes and electrolytes of Tympanotonus fuscatus after mild exposure.

\section{Materials And Methods}

Periwinkles (Tympanotonus fuscatus) of size between $4.5-5.5 \mathrm{~cm}$ were handpicked at the Eagle cement area of the New Calabar River near the Ignatius Ajuru University of Education Rumuolumeni, Port Harcourt. They were transported in plastic buckets to the Chemistry Department Laboratory of the University. Two hundred apparently healthy periwinkles were acclimated to laboratory conditions in plastic tanks of six litre capacity. The tanks were half filled with brackish water and sediments collected from same source. The 
acclimation was done for seven days. The substrate was prepared by air drying the sediment and then macerated in a mortar and sieved in $2 \mathrm{~mm}$ mesh.

$250 \mathrm{~g}$ of finely prepared sediment were put into each of the plastic tanks to serve as the substrate base. Completely randomized design (CRD) was used for the experiment. The experiment was divided into five treatment levels with two replicates. The test media were prepared in the following concentrations: $10.40 \mathrm{ml} / \mathrm{L}$, $15.6 \mathrm{ml} / \mathrm{L}, 21.00 \mathrm{ml} / \mathrm{L}, 26.00 \mathrm{ml} / \mathrm{L}$ and a control $(0.00 \mathrm{ml} / \mathrm{L})$ of diesel. Twelve of the test animals were introduced into each of the toxicant media. The content of the aquaria were washed thoroughly on the forth day and was renewed with fresh concentrations which lasted to the sixth day.

On the sixth day the periwinkles were removed from the toxicant and the shells were broken with a small rod and the tissues separated from the shell. The tissues were divided into the edible part (muscle) and the non edible part (viscera).

$0.5 \mathrm{~g}$ of the tissues were macerated or homogenized and mixed with $5 \mathrm{ml}$ de-ionized water for electrolyte analysis and another $0.5 \mathrm{~g}$ of the tissues were homogenized and mixed with $5 \mathrm{ml}$ of physiological saline for enzyme analysis. They were centrifuged at rate of 3000rpm for ten minutes and the supernatant poured into $5 \mathrm{ml}$ plain bottles. The samples were immediately transferred to the laboratory for analysis. The electrolytes were analysed by the method of Schales and Schales (1941), while the enzymes were analysed by the method of Reitman and Frankel (1957).

The result obtained were subjected to analysis of variance (ANOVA) using one way classification to test whether differences existed between the means. Where differences existed, Duncan's multiple range test was used to separate the means (Zar, 1984).

\section{Results}

In the vicera of tympanotonus fuscatus, aspartate transaminase (AST) activities were higher than the control value $(57.50 \pm 31.82)$. The percentage increase in AST activity were $282.60 \%(10.40 \mathrm{ml} / \mathrm{L}), 213.04 \%$ $(26.00 \mathrm{ml} / \mathrm{L}), 195.65 \%(21.00 \mathrm{ml} / \mathrm{L})$ and $134.78(15.60 \mathrm{ml} / \mathrm{L})$. Alanine transaminase (ALT) activity also were all higher than the control value of $40.00 \pm 28.28 \mathrm{IU} / \mathrm{L}$. The highest value obtained at $10.04 \mathrm{ml} / \mathrm{L}$ was $218.75 \%$ rise in activity. This was followed by $212.50 \%, 162.50 \%$ and $156.25 \%$ rise at $15.60 \mathrm{ml} / \mathrm{L}, 26.00 \mathrm{ml} / \mathrm{L}$ and $21.00 \mathrm{ml} / \mathrm{L}$ respectively. Alkaline phosphatase (ALP) activity in the treatment groups were higher in value than that of the control $(215.00 \pm 49.49 \mathrm{IU} / \mathrm{L})$ except at $10.40 \mathrm{ml} / \mathrm{L}$ where inhibition of $1.17 \%$ was recorded. The higher values were $81 \%, 80 \%$ and $27 \%$ rise at $26.00 \mathrm{ml} / \mathrm{L}, 15.40 \mathrm{ml} / \mathrm{L}$ and $21.00 \mathrm{ml} / \mathrm{L}$ respectively (Table 1 ). In the muscle, elevated activity of AST was observed in all the exposure concentrations above the control value of $137.50 \pm$ $60.10 \mathrm{IU} / \mathrm{L}$. the rise in activity were $160.0 \%, 147.27 \%, 114 \%$ and $69 \%$ at $10.40 \mathrm{ml} / \mathrm{L}, 26.00 \mathrm{ml} / \mathrm{L}, 15.60 \mathrm{ml} / \mathrm{L}$ and $21.00 \mathrm{ml} / \mathrm{L}$ respectively. However, ALT activity declined in all the exposure concentrations as against the control value $(227.50 \pm 45.96 \mathrm{IU} / \mathrm{L})$ except at $15.60 \mathrm{ml} / \mathrm{L}$ which was equal in to the control value. The inhibitions were $9.89 \%(10.40 \mathrm{ml} / \mathrm{L}), 24.18 \%(26.00 \mathrm{ml} / \mathrm{L})$ and $53.85 \%$ at $21.00 \mathrm{ml} / \mathrm{L}$. ALP activity declined in all the exposure concentrations which were $10.17 \%(21.00 \mathrm{ml} / \mathrm{L}), 23.73 \%(26.00 \mathrm{ml} / \mathrm{L}), 30.57 \%(15.60 \mathrm{ml} / \mathrm{L})$ and $33.90 \%$ at $10.40 \mathrm{ml} / \mathrm{L}$ as against the control value of $147.50 \mathrm{IU} / \mathrm{L}$ (Table 2 ).

In the viscea of Tympanotonus fusatus, the levels of sodium ion $\left(\mathrm{Na}^{+}\right)$depreciated in all the exposure concentrations. The de crease in levels were $4.76 \%(26.00 \mathrm{ml} / \mathrm{l}), 16.67 \%(21.00 \mathrm{ml} / \mathrm{L}), 52.38 \%(10.40 \mathrm{ml} / \mathrm{L})$ and $60.00 \%$ at $15.60 \mathrm{ml} / \mathrm{L}$ as against the control value of $105.00 \pm 7.07 \mathrm{meq} / \mathrm{L}$. potassium ion $\left(\mathrm{K}^{+}\right)$also depreciated in value in all the exposure concentrations. However, the depreciations were not concentration dependent. The percentage decline in levels obtained were $51.25 \%(26.00 \mathrm{ml} / \mathrm{L}) 47.97 \%(21.00 \mathrm{ml} / \mathrm{L}), 46.34 \%(10.40 \mathrm{ml} / \mathrm{L})$ and $45.53 \%(15.60 \mathrm{ml} / \mathrm{L})$. chloride ion $\left(\mathrm{Cl}^{-}\right)$declined in levels in all concentrations except at $15.60 \mathrm{ml} / \mathrm{L}$ which was $21.21 \%$ above the control being $82.50 \pm 88.38 \mathrm{meq} / \mathrm{L}$. the decreased levels were $51.52 \%(26.00 \mathrm{ml} / \mathrm{L})$, $27.88 \%(21.00 \mathrm{ml} / \mathrm{L})$ and $21.82 \%$ at $10.40 \mathrm{ml} / \mathrm{L}$ (Table3). In the muscle $\mathrm{Na}^{+}$, value depreciated in all the test concentrations except at $15.60 \mathrm{ml} / \mathrm{L}$ which was $33.33 \%$ above the control value of $67.50 \pm 24.75 \mathrm{meq} / \mathrm{L}$. Decline of $33.33 \%$ were observed at $21.00 \mathrm{ml} / \mathrm{L}$ and $26.00 \mathrm{ml} / \mathrm{L}$ concentrations while that observed at $10.40 \mathrm{ml} / \mathrm{L}$ was $25.93 \%$ lower in value. $\mathrm{K}^{+}$ion decreased in levels as well in all the concentrations, the highest being $52.70 \%(15.60 \mathrm{ml} / \mathrm{L})$, which was followed by $48.65 \%(10.40 \mathrm{ml} / \mathrm{L})$, then $14.86 \%(26.00 \mathrm{ml} / \mathrm{L})$ and $12.57 \%(21.00 \mathrm{ml} / \mathrm{L})$ as against the control value of $18.50 \pm 1.41 \mathrm{meq} / \mathrm{L}$. $\mathrm{Cl}^{-}$ion declined in all the exposure concentrations except at $26.00 \mathrm{ml} / \mathrm{L}$ which was $98.95 \%$ above the control value of $47.50 \pm 38.89 \mathrm{meq} / \mathrm{L}$. decline of $68.42 \%, 58.42 \%$ and $27.37 \%$ were observed $10.40 \mathrm{ml} / \mathrm{L}, 15.60 \mathrm{ml} / \mathrm{L}$ and $21 \mathrm{ml} / \mathrm{L}$ respectively.

Table 1. AST, ALT and ALP activities in the viscera of Tympanotonus fuscatus exposed to petrol for six days.

\begin{tabular}{|c|c|c|c|c|c|c|}
\hline $\begin{array}{l}\text { Concentration } \\
\text { of petrol(ml/L) }\end{array}$ & AST(IU/L) & $\begin{array}{l}\text { \% of } \\
\text { control }\end{array}$ & ALT(IU/L) & $\begin{array}{l}\text { \% of } \\
\text { control }\end{array}$ & ALP(IU/L) & $\begin{array}{l}\% \\
\text { control }\end{array}$ \\
\hline 0.00 & $57.50 \pm 31.82^{\mathrm{c}}$ & 100 & $40.00 \pm 28.28^{\mathrm{c}}$ & 100 & $215.00 \pm 49.49^{\mathrm{b}}$ & 100 \\
10.40 & $220.00 \pm 56.57^{\mathrm{a}}$ & 382.61 & $127.50 \pm 60.10^{\mathrm{a}}$ & 318.75 & $212.50 \pm 10.61^{\mathrm{b}}$ & 98.83 \\
\hline
\end{tabular}


Petrol Induced Alteration In Enzymes And Electrolytes In Tympanotonus Fuscatus After Exposure

\begin{tabular}{|c|c|c|c|c|c|c|}
\hline 15.60 & $135.00 \pm 28.28^{\mathrm{bc}}$ & 234.78 & $125.00 \pm 68.01^{\mathrm{a}}$ & 312.50 & $387.50 \pm 215.67^{\mathrm{a}}$ & 180.23 \\
21.00 & $170.00 \pm 49.50^{\mathrm{b}}$ & 295.65 & $102.50 \pm 28.50^{\mathrm{b}}$ & 256.25 & $375.00 \pm 28.28^{\mathrm{a}}$ & 127.90 \\
& & & & & & \\
26.00 & $180.00 \pm 313.04^{\mathrm{b}}$ & 313.04 & $105.00 \pm 56.57^{\mathrm{b}}$ & 262.50 & $390.00 \pm 70.71^{\mathrm{a}}$ & 181.39 \\
\hline
\end{tabular}

Means with the same alphabeth in the same column are not significantly different $(\mathrm{P}>0.05)$.

Table 2. AST, ALT and ALP activities in the muscle of Tympanotonus fuscatus exposed to petrol for six days.

\begin{tabular}{|l|l|l|l|l|l|l|}
\hline $\begin{array}{l}\text { Concentration of } \\
\text { petrol(ml/L) }\end{array}$ & AST(IU/L) & $\begin{array}{l}\% \text { of } \\
\text { control }\end{array}$ & ALT(IU/L) & $\begin{array}{l}\% \text { of } \\
\text { control }\end{array}$ & ALP(IU/L) & $\begin{array}{l}\% \\
\text { control }\end{array}$ \\
\hline 0.00 & $137.50 \pm 60.10^{\mathrm{c}}$ & 100 & $227.50 \pm 45.96^{\mathrm{a}}$ & 100 & $147.50 \pm 24.75^{\mathrm{a}}$ & 100 \\
10.40 & $357.50 \pm 31.82^{\mathrm{a}}$ & 260.00 & $205.00 \pm 14.140^{\mathrm{ab}}$ & 90.11 & $97.50 \pm 10.61^{\mathrm{bc}}$ & 66.10 \\
15.60 & $295.00 \pm 0.00^{\mathrm{ab}}$ & 214.55 & $227.50 \pm 81.32^{\mathrm{a}}$ & 100 & $102.50 \pm 38.89^{\mathrm{b}}$ & 69.49 \\
21.00 & $232.50 \pm 38.89^{\mathrm{ab}}$ & 169.09 & $105.00 \pm 28.28^{\mathrm{bc}}$ & 46.15 & $102.50 \pm 60.10^{\mathrm{b}}$ & 89.83 \\
26.00 & $340.00 \pm 148.49^{\mathrm{a}}$ & 247.27 & $172.50 \pm 123.74^{\mathrm{b}}$ & 75.82 & $112.50 \pm 10.61^{\mathrm{ab}}$ & 76.27 \\
\hline
\end{tabular}

Means with the same alphabeth in the same column are not significantly different $(\mathrm{P}>0.05)$.

Table 3. Sodium, potassium and chloride ion in the muscle of Tympanotonus fuscatus exposed to petrol for six days.

\begin{tabular}{|l|l|l|l|l|l|l|}
\hline $\begin{array}{l}\text { Concentration of } \\
\text { petrol }(\mathrm{ml} / \mathrm{L})\end{array}$ & $\mathrm{Na}^{+}(\mathrm{meq} / \mathrm{L})$ & $\%$ of control & $\mathrm{K}^{+}(\mathrm{meq} / \mathrm{L})$ & $\begin{array}{l}\% \text { of } \\
\text { control }\end{array}$ & $\mathrm{Cl}(\mathrm{m}$ eq/L) & $\begin{array}{l}\% \\
\text { control }\end{array}$ \\
\hline 0.00 & $105.00 \pm 7.07 \mathrm{a}$ & 100 & $30.75 \pm 12.37^{\mathrm{a}}$ & 100 & $82.50 \pm 88.38^{\mathrm{b}}$ & 100 \\
10.40 & $50.00 \pm 0.00^{\mathrm{c}}$ & 47.62 & $16.25 \pm 1.06^{\mathrm{b}}$ & 53.66 & $64.50 \pm 21.29^{\mathrm{b}}$ & 78.18 \\
15.60 & $42.50 \pm 3.54^{\mathrm{d}}$ & 40.00 & $16.75 \pm 8.86^{\mathrm{b}}$ & 54.47 & $100.00 \pm 0.00^{\mathrm{a}}$ & 121.21 \\
21.00 & $87.50 \pm 53.03^{\mathrm{b}}$ & 83.33 & $16.00 \pm 4.95^{\mathrm{b}}$ & 52.03 & $59.50 \pm 14.85^{\mathrm{c}}$ & 72.12 \\
26.00 & $100.00 \pm 70.71^{\mathrm{a}}$ & 95.24 & $15.00 \pm 6.36^{\mathrm{b}}$ & 48.78 & $40.00 \pm 42.43$ & 48.48 \\
\hline
\end{tabular}

Means with the same alphabet in the same column are not significantly different $(\mathrm{P}>0.05)$

Table 4.Sodium, potassium and chloride ion in the muscle of Tympanotonus fuscatus exposed to petrol for six

\begin{tabular}{|l|l|l|l|l|l|l|}
\hline $\begin{array}{l}\text { Concentration } \\
\text { of petrol(ml/L) }\end{array}$ & $\mathrm{Na}^{+}(\mathrm{meq} / \mathrm{L})$ & $\%$ of control & $\mathrm{K}^{+}(\mathrm{meq} / \mathrm{L})$ & $\begin{array}{l}\% \text { of } \\
\text { control }\end{array}$ & $\mathrm{Cl}\left(\mathrm{m}^{-}\right.$eq/L) & $\begin{array}{l}\% \\
\text { control }\end{array}$ \\
\hline 0.00 & $67.50 \pm 24.75^{\mathrm{b}}$ & 100 & $18.50 \pm 1.41^{\mathrm{a}}$ & 100 & $47.50 \pm 38.89^{\mathrm{b}}$ & 100 \\
10.40 & $50.00 \pm 0.00^{\mathrm{b}}$ & 74.07 & $9.50 \pm 6.36^{\mathrm{b}}$ & 51.35 & $15.00 \pm 7.07^{\mathrm{d}}$ & 31.58 \\
15.60 & $90.00 \pm 49.50^{\mathrm{a}}$ & 133.33 & $8.75 \pm 5.30^{\mathrm{b}}$ & 47.30 & $19.75 \pm 13.79^{\mathrm{d}}$ & 41.58 \\
21.00 & $45.00 \pm 7.07^{\mathrm{c}}$ & 66.67 & $16.00 \pm 4.95^{\mathrm{ab}}$ & 87.49 & $34.50 \pm 7.07^{\mathrm{c}}$ & 72.63 \\
26.00 & $45.00 \pm 7.07^{\mathrm{c}}$ & 66.67 & $15.00 \pm 6.36^{\mathrm{ab}}$ & 85.14 & $94.50 \pm 64.34^{\mathrm{a}}$ & 198.95 \\
\hline
\end{tabular}

Means with the same alphabeth in the same column are not significantly different $(\mathrm{P}>0.05)$.

\section{Discussion}

Behaviour of animals is known as a neurotropically mediated phenomenon which is mediated by neurotransmitter substances (Sambasiva, 1999). The increase and decrease in enzyme activities observed in this study is similar to ones observed in other studies (Mousa et al., 2008; Gabriel et al., 2011; Humtsoe et al., 2007). In stress mediated reactions organisms need energy to detoxify, biotransform and excrete the toxicant so that the effect of the toxicant can be minimized. This can be achieved by the use of immediate and principal source of energy which is carbohydrate (Umminger, 1977). To achieve this, AST and ALT activities may either be stepped up or down so that transamination processes would favour the organisms need. Increase in AST and ALT in the muscle of the periwinkle infers active of transamination (the interplay between carbohydrate and protein synthesis during energy demand) in the muscle of the periwinklr, (Gabriel et al., 2011). The increase in the transaminases is to gain energy in order to cope with the stressed condition which resulted from higher demand carbohydrate and its precursors to keep both the glycolytic pathway and TCA cycles at sustained levels to cope with the energy required during stress (Tiwari and Singh, 20004). 
Elevation of the transaminases is an indication of stress augmentation resulting from toxicants which in this case is the petrol. Increase in the transaminases is in line with increasing energy demands to fulfill the organisms need through amino acids (Tiwari and Singh, 2004). However, in the viscera, their was observed increase in AST and decrease in ALT after exposure to petrol. This response may be a counter reaction to Maintain the integrity of the organ and to offer protection to the structural integrity of the cellular membrane (Pari and Amali, 2005). It may also suggest that their were no damage to the parenchymatous tissue and the permeability and integrity of the cell membrane were intact. The increase and decrease observed in the organs is also an indication of concentration dependent enzymatic responses of the enzymes in the target tissue/organ of the experimental animal under petrol toxicity (Gabriel et al., 2011). Decrease in these enzymes can also be attributed to inhibition of enzyme synthesis (Mousa et al.,2004; Shalaby et al., 2007) as a result of petrol toxicity. There was a marked increase in ALP activity in the muscle with a corresponding decrease in the viscera of the periwinkle in this study. ALP and acid phosphatase (ACP) are important biomarkers because of their presence in all tissues of organism and are involved in adaptive cellular response to pollutants (Lohner et al., 2001). ALP plays the major role in the phosphate metabolism and without enzyme the external membrane may be damaged by toxicants (Durriue and Tran-Minh, 2002). Increase in ALP may have resulted possibly from phosphate ingestion by the periwinkle. ALP is a hydrolytic enzyme that is responsible with transphosphorylation processes and plays an important role in the general energetics of an organism such as the conversion of NADP to NAD (Morton, 1995; Sreekala and Zutshi 2010) and are associated with metabolic transport of phospholipids, phosphoproteins, nucleotides and carbohydrates and with synthesis of proteins (Srivastava et al., 1995). ALP splits various phosphate esters at an alkaline $\mathrm{pH}$ and mediates membrane transport. Decrease in ALP activity can result in altered transport and inhibitory effect on cell growth and multiplication (Goldfischer et al., 1964). ALP promotes glycogen synthesis by inactivating phosphorylase enzymes (Parthasarathi and Karuppasamy, 1998), therefore its inhibition can cause reduced glycogen content. Reduction in ALP activity can also result from severe acidosis (Shaikila et al., 1993)and this in turn could be adaptive for the fish to meet the energy required by the anaerobic breakdown of glycogen. Inhibition of ALP could also be from the interaction of the toxicant with co-factors and regulators (Sarabadhikary and Sur, 1992; Ramesh et al., 1994). The decrease in this enzyme indicates a disturbance in the structure and integrity of cell organelles such as endoplasmic reticulum and membrane transport system (Nchumbeni et al., 2007) of the organism which in this case is the periwinkle.

As the primary link between environmental change and physiological response, the neuro-endocrine system is a critical part of osmoregulation. The capacity to regulate ions in the face of changing environmental conditions due to the presence of toxicants is an obvious necessity for organisms that live in water (McCormick, 2001). There was observed decrease in the electrolytes $\left(\mathrm{Na}^{+}, \mathrm{K}^{+}\right.$and $\left.\mathrm{Cl}^{-}\right)$in all the tissues tested.

The electrolytes are distributed in solution throughout all the body fluids. The cations are the ions of sodium, potassium, calcium and magnesium with the predominating ones being sodium and potassium. The major anions are the chlorides and hydrogen carbonates. Maintenance of constant internal ion concentration is essential for the active regulation of water influx and ion efflux in aquatic organisms (Karthikeyan et al., 2006). Studies have shown that both organic and inorganic pollutants impair ionic balance in various biological systems (Oksama and Kristoffersson, 1980; Gabriel et al., 20009; Uboh et al., 2012). $\mathrm{Na}^{+}$and $\mathrm{K}^{+}$ion are essential for the activity of many enzymes and have been implicated in the transport of ATP which participates in several metabolic processes such as $\mathrm{Na}^{+}$and $\mathrm{K}^{+}$ATPase which are located the cell membrane (Rajanna et al ., 1981). Decrease in these ions is an indication of stress mediated injury in the tissues (Olwole, 2001; Gabriel et al 2009). Decrease in $\mathrm{Na}^{+}$indicates a change in permeability properties of the muscle and viscera of the periwinkle (Karthikeyan et al., 2006). Decrease in these $\left(\mathrm{Na}^{+}, \mathrm{K}^{+}\right.$and $\left.\mathrm{Cl}^{-}\right)$implies that the rate at which these ions are lost to the environment is greater than their absorption by the organs from the environment.

$\mathrm{Na}^{+}$and $\mathrm{Cl}^{-}$are used as index of osmoregulation because they react similarly in organisms under situations of strong circulating levels and are useful in stress measurement. The decrease in $\mathrm{Na}^{+}$and $\mathrm{Cl}^{-}$contents may be due to increase in the permeability of the organs or inhibition of active transport, aconsequence of petrol toxicosis. According to Pic (1998) and Ando (1981) $\mathrm{Cl}^{-}$permeability is increased in stressful animals resulting in an enhanced efflux rate and an appriopriate decrease of $\mathrm{Cl}^{-}$ion concentration. $\mathrm{Cl}^{-}$decrease in the periwinkle might also have resulted from reduced activity of carbonic anhydrate or sterodogenesis. The decrease in $\mathrm{K}^{+}$ion concentration have been associated with stress (Karthikeyan et al., 2006). $\mathrm{K}^{+}$is essential for the activity of nerves and is present in nerve fibres which are related to carbohydrate metabolism (Shaanmugan, 1993). However, reduction in $\mathrm{K}^{+}$ion can be attributed to increase in extracellular space.

The result of this study reveals that petrol is toxic to periwinkle and causes underlying injury in its tissues, therefore its use should be effectively managed and where there is spill adequate clean-up exercise should be carried out immediately. 


\section{References}

[1]. Abu-Hilal, A. H. and Khordagui, H. K. (1994). Petroleum hydrocarbons in the Mearshore marine sediments of the United Arab Emirates. Environ. Pollut. 85: 315-319.

[2]. Agbogidi, O. M., Okonta, I. S. and Dolor, D. E. (2005). Socio-economic and environmental impact of crude oil exploration and production on agricultural production. A case study of Edjaba and Kokori communities in Delta State. Global Journal of Environ. Sci. 4(2): 171-176

[3]. Ando, M. (1981). Effects of ouabain on chloride movements across the seawater eel intestine. Journal of Comp. Physiol. 145: 7379.

[4]. Atlanta, G. A. (1999). Toxicological profile for total petroleum hydrocarbons (TPH), Agency for Toxic Substance and Disease Registry (ATSDR), Public Health Service U S Department of Health and Human Services. Marine pollution. Oxford University Press, Oxford, 172pp.

[5]. Clark, R. B. (1992). Marine Pollution. Oxford University Press, Oxford, 172pp

[6]. Benson, N. U., Essien, J. P. , Ebong, G. A. and Williams, A. B. (2008). Total petroleum hydrocarbons in Macura reptantia Procambarus of Clarkia and Benthic sediments from the Qua Iboe estuary Nigeria. Environmentalist, 28: $275-282$.

[7]. Doerffer, J. W. (1992). Oil spill response in the marine environment. Pergamon Press, England, 391pp.

[8]. Durrieu, C. and Tran Minh, C. (2002). Optical algal biosensor using alkaline phosphatase for determination of heavy metals. Ecotox. Environ. Saf., 51(3): 206-209.

[9]. Egonmwan, I. R. (1980). On the biology of Tympanotonus fuscatus var radula (Gastropoda, Prosobranchia Potamidae). M. Sc. Thesis, University fo Lagos ,145pp.

[10]. EHC 20 (1982). Selected petroleum products; In Environmental Health Criteria 20, United Nations Environmental Programme. The Intl. Org. and WHO, Geneva, pp 243-246.

[11]. Gabriel, U. U., Jack I. R., Edori, O. S. and Egobueze, E. (2009). Electrolytes in selected tissues of Heterobranchus bidorsalis treated with sublethal levels of Cypermethrin. Ethiopian Journal of Environmental Studies and Management. 2(3):83-87.

[12]. Gabriel, U. U., Jack I. R., Edori, O. S. and Egobueze, E.and Edori, O. S (2011). Impact of cypermethrin on selected enzymes in tissues of Heterobranchus bidorsalis. West African Journal of Applied Ecology, 18: 121-127.

[13]. Goldfischer, S., Essner, E. and Novikoff, A. B. (1964). The localization of phosphatase activities at level of ultrastructure. J. Histochem. Cytochem. 12: 72-95.

[14]. Kato, M., Rocha, M. L, Carvallio, A. B., Chares, M. E., rana, M. C. and Oliverira, F. C. (1996). Occupational exposure to neurotoxicants: preliminary survey in five industries of Camacari petrochemical complex, Brazil. Environ. Res. 136: 49-56. Karthikeyan, S., Jambulingam, M., Sivakumar, R., Shekhar, A. P. and Krithka, J. (2006). Impact of textile effluents on fresh water fish Mastacembelus armatus(Cuv and Val).E- journal of Chemistry, 3(13): 303-306. Lohner, T. W., Reash, J. R. and Williams, M. (2001). Assessment of tolerant sunfish populations (Lepomis Sp.) inhabiting selenium-laden coal ash effluent 2. Tissue biochemistry evaluation. Ecotoxicol. Environ. Saf. 50: 217-224.

[15]. Law, R. J. and Biscaga, J. L. (1994). Polycyclic aromatic hydrocarbons (PAH). Problems and progress in sampling, analysis and interpretation. Marine pollut. Bull. 29, 235-241.

[16]. McCormick, S. D. (2001). Endocrine control of osmoregulation in Teleost fish. Amer. Zool.. 41: $781-794$.

[17]. Medeiros, P. M., Bicego, M. C., Castelao, R. M., Rosso, C. D., Fillmann, G. and Zambono, A. J. (2005). Natural and anthropegenic hydrocarbons input to sediments by two faunal invertebrates. Marine Ecol. Progser. 123: 107-124.

[18]. Morton, R. K. (1995). The action of purified alkaline phosphatase on di- and triphosphopyridine nucleotides. Biochemistry journal, 61: 240-244.

[19]. Mousa, M. A. (2004). Toxicological studies on the effect of machete herbicide on some fish species. Egypt. J. Appl. Sci., 19(5): 111.

[20]. Mousa, M. A., Ahmed, M., El-Ashram, M. and Hamed, M. (2008). Effect of neem leaf extract on freshwater fishes and zooplankton community. $8^{\text {th }}$ International Symposium on Tilapia in Aquaculture.

[21]. Nchumbeni, H., Davoodi, R. ,Kulkarni, G. G. and Chavan, B. (2007). Effect of arsenic on the enzymes of the rohu carp, Labeo rohita (Hamilton, 1822). The Raffles Bull. of Zoology Supplement, 14: 17-19.

[22]. Oluwole, S. F. (2001). Effects of garlic on some haematological and biochemical parameters. African Journal of Biomedical Research.4:139-141.

Oksama, M. and Kristoffersson, R. (1980). Effects of phenol and 4- chlorophenol on ionic regulation in Mesidotea entomon (crustacea) in brackishwater 1. Ann. Res. 17(3): 281-285.

[23]. Pari, L. and Amali, R. D. (2004). Protective role of tetrahydrocurcumin (THC) an active principle of turmeric on chloroquine induced hepatoxicity in rats. J. Pharmaceut. Sci. 8(1): 115-123.

[24]. Parthasarathi, K. and Karuppasamy, R, (1998). Fenvalerate impact on tissue acid and alkaline phosphatase activity of the fish, Channa puntatus (Bloch). Poll. Res. 179(3): 281-285.

[25]. Pic, P. (1998). Journal of Comp. Physiol. 123: 155-162.

[26]. Rajanna, B., Chapatwala, K. D., Vaishnav, D. D. and Desaiah, D. (1981). Changes in ATphase activity in tissues of rat fed on cadmium. J. Environ. Biol. 2(1): 1-9.

[27]. Ramesh, M., Manavalaramanujam, R. and Sivakumari, K. (1994). Effect of vegetable factory effluent on alkaline phosphatase activity in a fresh water teleost fish, Cyprinus carpio. Indian J. Environ. Hlth. 36(3): 192-196.

[28]. Reitman, S. and Frankel, S. (1957). A colorimetric method for the determination of glutamic-oxaloacetic and glutamic-pyruvic transaminases. Amer. J. Clin. Pathol. 33:1-13.

[29]. Sambasiva Rao, K. R. S. (1999). Pesticide impact on fish metabolism. New Delhi, Discovery Publishing House, 66-70.

[30]. Sarabadhikari, A. and Sur, R. K. (1992). Effect of short duration exposure to methyl parathion followed by recovery of activities of some enzymes of the fish Oreochromis niloticus (Smith). Environ. Ecol. 10: 333-340.

[31]. Schales, O. and Schales, S. S. (1941). A simple and accurate method for the determination of chloride ion in biological fluid. J. Biol. Chem. 140:879-884. Indian J. Exptl. Biol. 33: 284-286.

[32]. Shaanmugan, A. (1993). Enzymes and carbohydrate metabolism in "Fundamentals of biochemistry for medical students" $7^{\text {th }}$ edition (Ed). Karthik Printers. Madras India, 358; 145-146.

[33]. Shaikila, B. J., Thangavel, P. and Ramaswamy, M. (1993). Adaptive trends in tissue acid and alkaline phosphatases of Sarotherodon mossambica (Peters) under sevin toxicity. Indian J. Environ. Hlth. 35(1): 36-39.

[34]. Shalaby, A. M., Mousa, M. A. and El-Dian, H. A. (2007). Toxicological effect butataf herbicide on some physiological aspects and the reproductive performance of Nile tilapia, Oreochromis niloticus. Egypt. J. Aquat. Biol. And Fisher. 11(2): 145-163.

[35]. Sreekala, G. and Zutshi, B. (2010). Acid and Alkaline phosphatase activity in the tissue of Labeo rohita from freshwater lakes of Banglore. Journal of Life Sciences, 2: 365-372. 
[36]. Srivastava, P. P.; Chaudhuri, A., Reddy, D. K., Thangavel, K. and Prasad, R. K. (1995). Purification and characterization of alkaline phosphatase from fat body of tropical tasar silkworm, Antheraca mylitta. Indian J. Exptl Biol. 33: 284-284.

[37]. Tiwari, S. and Singh, A. (2004). Piscidal activity of alcoholic extract of Nerium indicum leaf and their biochemical stress response on fish metabolism. Afri. J. Trad. CAM. 1: 15-29.

[38]. Uboh, F. E., Akpanabiatu, M. I., Aquaisua, A. N. and Bassey, E. I. (2012). Oral exposure to nitrocellulose thinner solvent induces nephrotoxicity in in male albino wister rats. Journal of Pharmacology and Toxicology. 10: 1-9.

[39]. Umminger, B. L. (1977). Relation of the whole blood sugar concentration in vertebrate to standard metabolic rate. Comp. Biochem. Physiol. 55: 457-460.

[40]. Zar, H. K. (1984). Statistical tools for scientific analysis. Oxford Publishers, London, 319pp. 